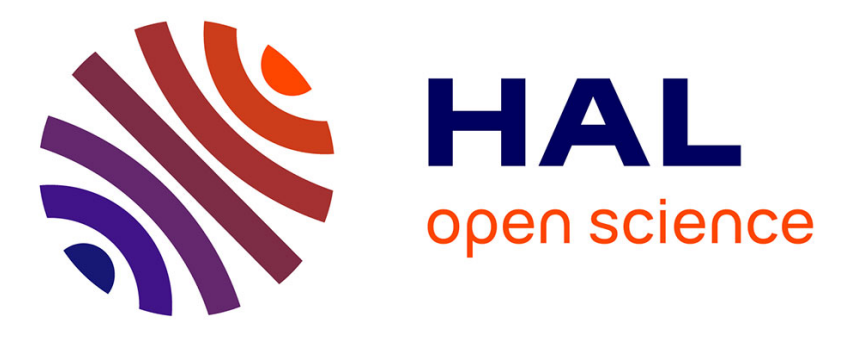

\title{
Study of DC-DC output serial connection for photovoltaic distributed systems
}

Youssef El Basri, Margot Gaetani-Liseo, Carlos Eduardo Carrejo Gonzalez, Adrien Ramond, Michaël Bressan, Corinne Alonso

\section{To cite this version:}

Youssef El Basri, Margot Gaetani-Liseo, Carlos Eduardo Carrejo Gonzalez, Adrien Ramond, Michaël Bressan, et al.. Study of DC-DC output serial connection for photovoltaic distributed systems. 2014 16th European Conference on Power Electronics and Applications (EPE'14-ECCE Europe), Aug 2014, Lappeenranta, Finland. 10.1109/EPE.2014.6911005 . hal-01703043

\section{HAL Id: hal-01703043 https://hal.science/hal-01703043}

Submitted on 23 Aug 2018

HAL is a multi-disciplinary open access archive for the deposit and dissemination of scientific research documents, whether they are published or not. The documents may come from teaching and research institutions in France or abroad, or from public or private research centers.
L'archive ouverte pluridisciplinaire $\mathbf{H A L}$, est destinée au dépôt et à la diffusion de documents scientifiques de niveau recherche, publiés ou non, émanant des établissements d'enseignement et de recherche français ou étrangers, des laboratoires publics ou privés. 


\title{
Study of DC-DC output serial connection for photovoltaic distributed systems
}

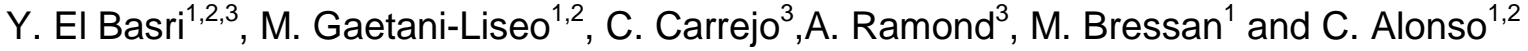 \\ 1 CNRS; LAAS; 7 Avenue du Colonel Roche, F-31077, TOULOUSE, FRANCE. \\ 2 UNIVERSITE DE TOULOUSE; UPS, INSA; LAAS; F-31400, TOULOUSE, FRANCE. \\ 3 TOTAL NEW ENERGIES - 2 Place Jean Miller - La Défense 6, F-92400 COURBEVOIE, FRANCE \\ E-mail: yelbasri@laas.fr, corinne.alonso@laas.fr
}

We present a study of work limits for two dc-dc converters associated in series. This type of structure is usually used to maximize the electrical energy production of a photovoltaic system when it is subjected to shading. We expose our study to research these limitations in the case of expensive shading.

DC-DC converters, series connections, photovoltaic systems, optimal matching in series connections

\section{INTRODUCTION}

Research on photovoltaic energy (PV) beyond improvements of cells efficiency have attracting significant attention in the field of power electronics and control algorithms associated in a perspective of maximizing the power generated by the modules. Thus, the development of control laws has recently taken an important place in the innovations made in terms of maximizing efficiency and safing operation. For this, control and electronics have become more complex and multitask. One trend is to approach the electronic interfaces close to the source by discretizing the control power architecture with several different power stages in cascade.

This approach induces research of better managements on differences energies produced. To illustrate our purpose, we have done compared studies on simple cases of connections. A comparison of various possible interconnections between a panel and its charge was proposed in Fig. 1. In the first configuration, PV modules are connected in serial in order to increase the output voltage to one DC-AC converters (Fig. 1.a). This configuration allow decreasing resistive losses, however this solution need the use of a bypass diode [1]. That means that if a production between the PV modules is different, the faulty module will be shorted. This strategy prevents the failed module to work in his receiver mode but a part of the production will be lost.

In the Fig. 1.b and Fig. 1.c, the bypass diode is integrated inside on or more micro-converters. Thus the power generated by each generator can be managed independently and therefore high improved. The main difference of this two distributed structure resides in the interconnection of their output. In the case $b$, the outputs of the micro-converters are connected in parallel and therefore share the same voltage, the total current is the sum of each output current. This configuration has no structural limitation because there is no dependency between the gain conversion stages. However due to a low output voltage and a high current input, the wiring losses will be greater than in the centralized solution. In case $\mathrm{c}$, the outputs are connected in series and this time sharing the same current [2], [3]. However, the output voltage of the power stages is then probable floating generating instabilities as voltage levels obtained. Robust control loops must constantly monitor that there is no drift [4]. This finding implies that the gains of the converters are connected. However, the advantage is that the currents are not added, minimizing the Joule losses. 


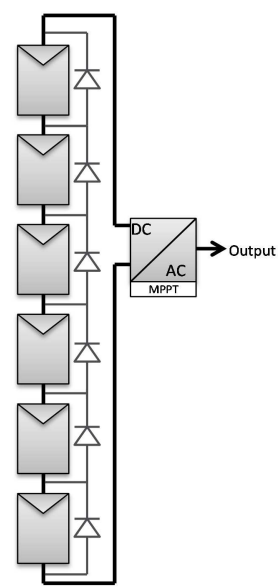

a) Centralized architecture

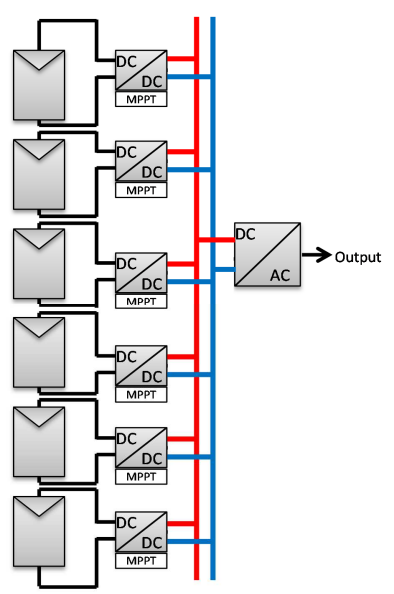

b) Distributed based on $\mu$-DC architecture in parallel

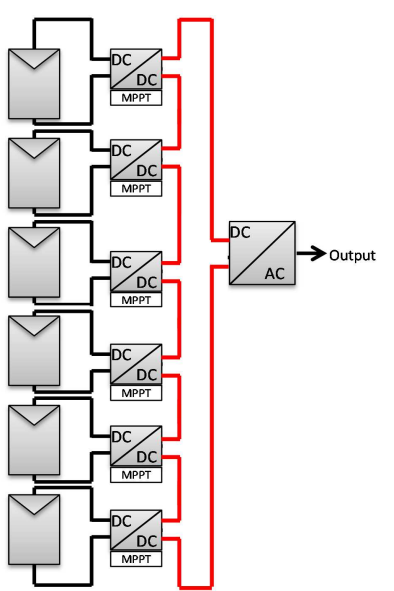

c) Distributed based on $\mu$-DC architecture in serie

Fig. 1. Photovoltaic power architecture

\section{PV models under shadow condition}

To well understand the phenomena involved in a moving shadow on the PV modules we use an electrical model of the cells taking into account the Bishop effect that will allow us to represent the inverse characteristic. In sunny conditions optimal voltage $\mathrm{V}_{\mathrm{OPT}}$ of solar cells have a value between $0.5 \mathrm{~V}$ and $0.7 \mathrm{~V}$. Therefore, the $\mathrm{PV}$ modules are most frequently made by connecting the cell in series in order to increase the voltage and facilitate the connection to the grid [5]. Thus cell will add the voltages with the same current flowing through the cells (Fig. 2). In the same principle, even if this configuration is rarely used to scale of the cell it is possible to connect them in parallel to increase the current [6]. These types of associations can be made without association's difficulty but it is recommended to have very similar electrical cells characteristics to avoid disparity and loss of performance. The serial and parallel photovoltaic cells configurations forming the photovoltaic generator (GPV) have its electrical characteristics which vary across the cell involving a mismatch. In the case of the serial connection, the mismatch limits the current across chain of cells. An occultation of a cell under these conditions creates a significant loss of power. When the difference of current between normal cells and the covered cell is large, the voltage of the cell becomes negative and passes in receiver operation. We must then consider the inverse characteristic of the cell and its avalanche area. Fig. 2.b shows the association of three cells of which is shaded. We can see that for a given current, the shaded cell have its voltage becomes negative and approach the breakdown voltage $\mathrm{V}_{\mathrm{BR}}[6]$, [7]

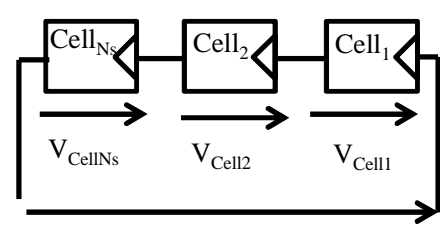

$\mathrm{V}_{\text {cell }} \times \mathrm{Ns}$

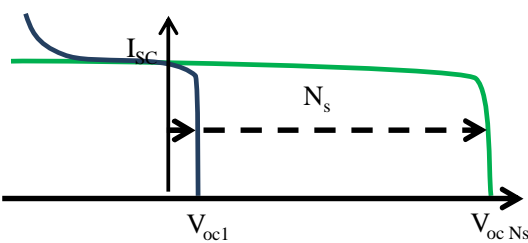

a) Without bypass diode

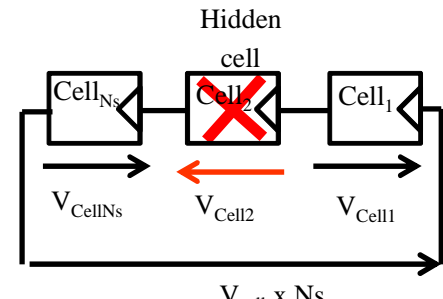

$\mathrm{V}_{\text {cell }} \times \mathrm{Ns}$

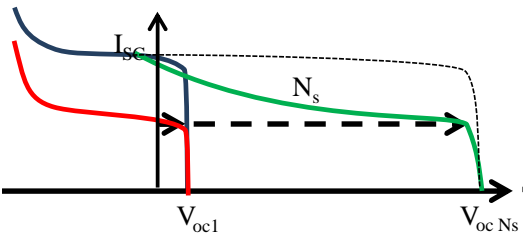

b) Without bypass diode and with hidden cell
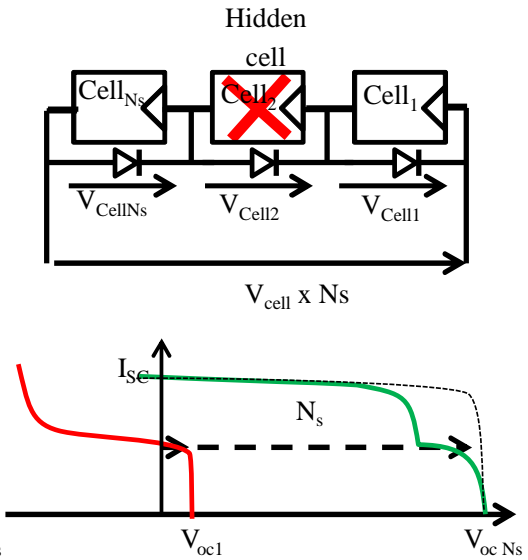

c) With bypass diode and with hidden cell

Fig. 2 : Serial connexion of PV cells under patial shading 
The photovoltaic cell in the receiving area will heat up and dissipate the excess temperature. This can lead to the deterioration of the cell. In the case where the current supplied by healthy cells allows polarizing the cell at a higher absolute value of $\mathrm{V}_{\mathrm{BR}}$, there will be a breakdown of the junction. The length of the chains of cells in a photovoltaic module is defined by this critical case, that is to say, if one cell is in the dark and all the other cells discharge inside of her. We find chains of cells to the silicon modules of about 20 cells for a voltage $\mathrm{V}_{\mathrm{BR}}$ around$20 \mathrm{~V}$. To increase the voltage and thus the number of cells in series, a protection diode is added in parallel for each string in order to bypass the shaded string if the voltage becomes negative [8], [9].

The effect of the bypass diode will result in a discontinuity of the characteristic $\mathrm{I}_{\mathrm{PV}}\left(\mathrm{V}_{\mathrm{PV}}\right)$ and did appear in the case of partial shading, two maximum powers (Fig. 2.c). At low voltage (high current), the failed module cannot supply the current and is totally disconnected. At high voltage (low current), the current string is limited by the lowest cell. In the first case, the faulty module does not produce energy, in the second case the faulty module limits the energy of non-shaded modules. This protection solution adopted by manufacturers has several disadvantages, the main ones:

- Creation of several maxima in the characteristic $\mathrm{P}_{\mathrm{PV}}\left(\mathrm{V}_{\mathrm{PV}}\right)$ generator,

- Power is lost during a shade of one cell of the string,

- $\quad$ Power is limited by the hidden cells.

Another protection diode called non-return diode is used to protect GPV against negative currents that could be come from other modules connected in parallel or the load (eg battery). In this case, the voltage is limited by the lowest string causing a loss of power.

Fig. 3 present the $\mathrm{P}(\mathrm{V})$ characteristic of a PV module composed of two groups, which one of the group is progressively shaded. We observe in the curve 1 , the discontinuity due to the bypass diode activation. In curve 2 , the power extracted in the case of discrete system. Finally, the distributed architecture is therefore useful when the powers differ between the modules.

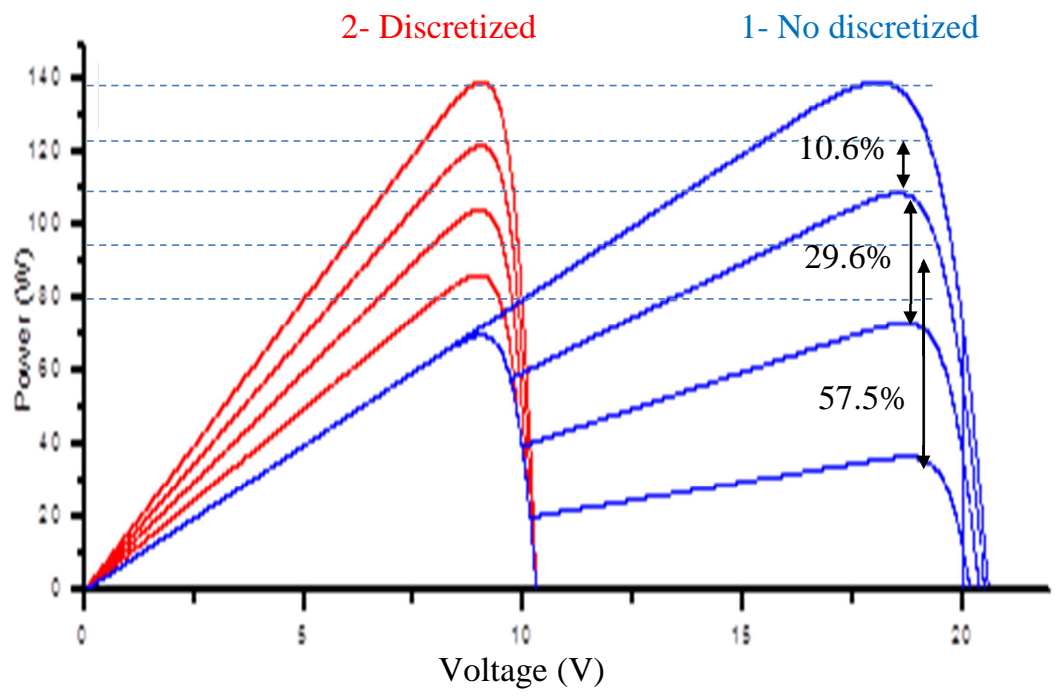

Fig. 3. Potential PV power gain for discretized PV module

\section{Study of converter series connection}

We analyze in our study the case of two DC-DC converters where the output is connect in series and then connect to a DC bus Vout (inverter input voltage or battery charger). Fig. 3 shows the schema where the currents Iout1 and Iout2 outputs are equal. 


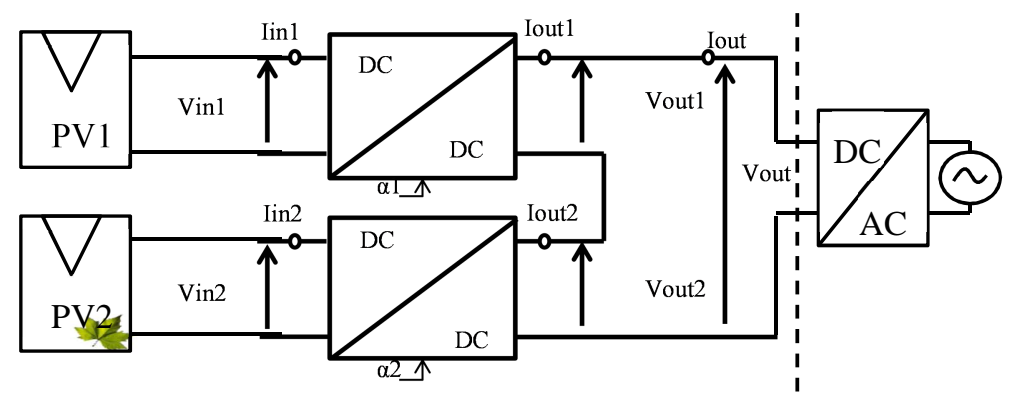

Fig. 4. Example of series of two DC-DC converters

We can determine from the diagram (Fig.4), the following equations (1) taking $\alpha 1$ and $\alpha 2$ as the conversion gains of the converters 1 and 2 starting from zero to infinity.

$$
\left\{\begin{array}{c}
V_{\text {out } 1}=\alpha_{1} * V_{\text {in } 1} \\
V_{\text {out } 2}=\alpha_{2} * V_{\text {in } 2} \\
V_{\text {out }}=V_{\text {out } 1}+V_{\text {out } 2} \\
V_{\text {in } 1} * i_{\text {in } 1}=V_{\text {out } 1} * i_{\text {out } 1} \\
V_{\text {in } 2} * i_{\text {in } 2}=V_{\text {out } 2} * i_{\text {out } 2}
\end{array}\right\} \quad\left\{\begin{array}{c}
i_{\text {out } 1}=\frac{i_{\text {in } 1}}{\alpha_{1}} \\
i_{\text {out } 2}=\frac{i_{\text {in } 2}}{\alpha_{2}} \\
i_{\text {out }}=i_{\text {out } 1}=i_{\text {out } 2}
\end{array}\right\}
$$

A simple analysis allows us to define the relationship between $\alpha 1$ and $\alpha 2$ as follows:

$$
\left\{\begin{array}{c}
\alpha_{1}=\alpha_{2} * \frac{\mathrm{i}_{\mathrm{in} 1}}{\mathrm{i}_{\mathrm{in} 2}} \\
\alpha_{1}=\frac{\mathrm{V}_{\text {out }}-\alpha_{2} * \mathrm{~V}_{\mathrm{in} 2}}{V_{\text {in } 1}}
\end{array}\right\}
$$

From (1) and (2), then we find:

$$
\left\{\begin{array}{l}
\alpha_{1}=\frac{\mathrm{V}_{\text {out }} * \mathrm{i}_{\text {in } 1}}{V_{\text {in } 1} * i_{i n 1}+V_{\text {in } 2} * i_{\text {in } 2}} \\
\alpha_{2}=\frac{\mathrm{V}_{\text {out }} * \mathrm{i}_{\text {in } 2}}{V_{i n 1} * i_{i n 1}+V_{i n 2} * i_{i n 2}}
\end{array}\right\}
$$

To define the limits of this interconnection, we perform an analytical study with the following change of variable and using as a reference the converter number 1 :

$$
A=\frac{\mathrm{V}_{\text {out }}}{\operatorname{Vin} 1} \quad B=\frac{\mathrm{i}_{\text {in2 }}}{i_{\text {in1 }}} \quad \mathrm{C}=\frac{V_{\text {in1 }}}{V_{\text {in } 2}}
$$

' $A$ ' defines the ratio between the output voltage $V_{\text {out }}$ and the input voltage of the first converter. ' $B$ ' and ' $C$ ' represent reciprocally the ratio between the two inputs current and the ratio between the two inputs voltage. Equation of each gain $\alpha$ will be defined according a fraction of the voltage and of the current of the first converter.

$$
\begin{gathered}
\alpha_{1}=\frac{\mathrm{V}_{\mathrm{in} 1} * \mathrm{i}_{\mathrm{in} 1}}{A *\left(V_{i n 1} * i_{i n 1}+C * B * V_{i n 1} * i_{i n 1}\right.} \\
=\frac{1}{A *(1+C * B)} \\
\alpha_{2}=\frac{B * \mathrm{~V}_{\mathrm{in} 1} * \mathrm{i}_{\mathrm{in} 1}}{A *\left(V_{i n 1} * i_{i n 1}+C * B * V_{i n 1} * i_{i n 1}\right.} \\
=\frac{\mathrm{B}}{A *(1+C * B)}
\end{gathered}
$$


In the case of PV application, the variation of the irradiation impact principally the PV current due to the exponential behavior of PV panel according to the PV voltage. In the first approach we will take account just the current variation and fix $\mathrm{V}_{\text {in2 }}=\mathrm{V}_{\text {in1 }}$ and therefore $\mathrm{C}=1$.

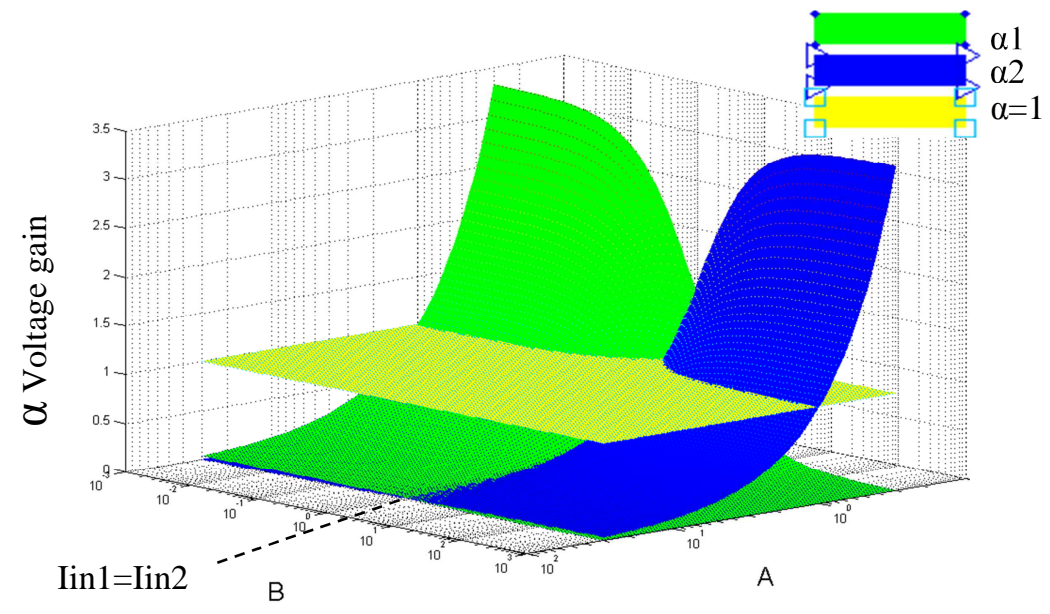

Fig. 5. Conversion gain between the voltage ratio and the current ratio for $\operatorname{Vin} 1=\operatorname{Vin} 2$.

Fig. 5 shows a 3D view of $\alpha 1$ and $\alpha 2$ according to A and $\mathrm{B}$. We also represented the passage from the buck mode to the boost mode with the area define by $\alpha=1$. We could see that there areas define four working zones where this converter operate in : "Buck-Buck", "Boost-Buck", "Buck-Boost" and "Boost-Boost". Thus, from the solution (4)=1 and (5)=1, it is possible to know the limit when the converter switching from the step down mode to the step up mode.

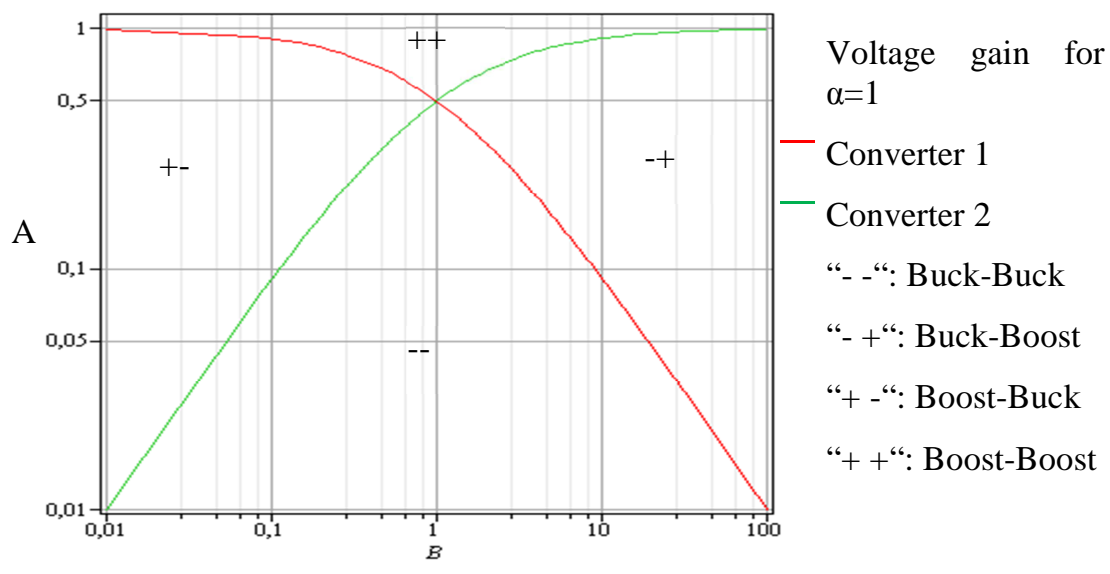

Fig. 6. 2D section of the Fig. 4 for $\alpha=1$ and Vin1=Vin2

Fig. 6 present the resolution evolution when Vin1=Vin2. We find that for Iin1=Iin2 a gain for the two stage equal to the half of the ratio voltage 'A'. In the other hand, if the ratio between the voltages is different (Vin $1 \neq$ Vin2), this characteristic will be moved (Fig. 7), this phenomena implies that the size of each zones change. To define the limits of the system, we must then consider the minimum and maximum conversion gain of a classical converter. 


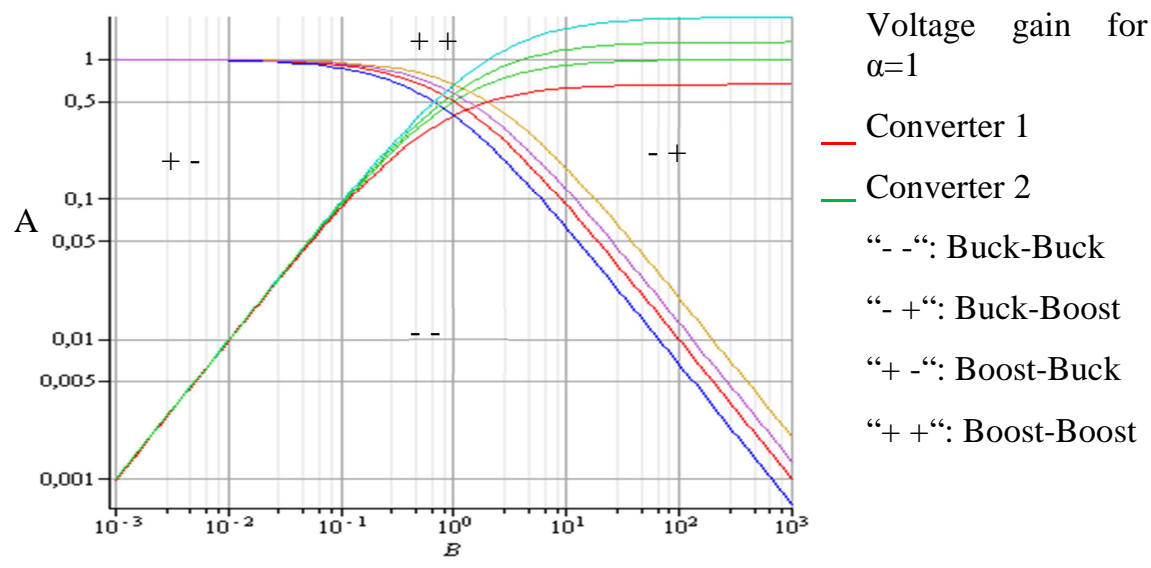

Fig. 7. 2D section of the Fig. 4 for $\alpha=1$ and Vin $1 \neq V$ Vin2

Fig. 8 shows the curve of the gain of the two converters when the conversion gain is 0.25 for the buck mode and 4.0 for the boost mode. The operation areas are then very small and the possibility to find an operating point then depends on the maximum and minimum gain, the report of the decoupling between the two input currents and finally the output voltage.

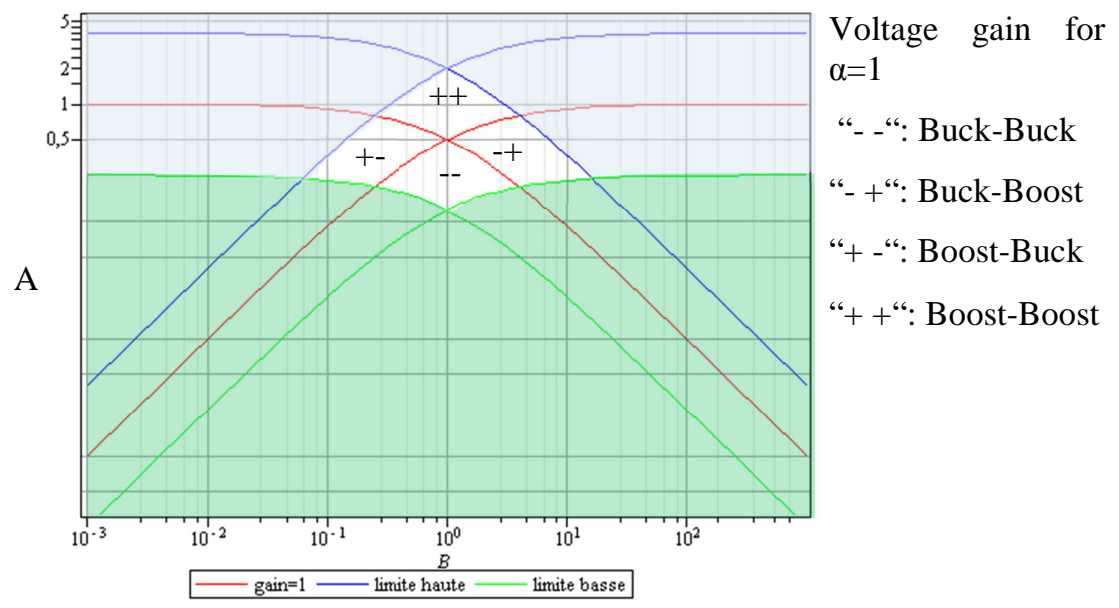

Fig. 8. 2D section of the Fig. 4 for $\alpha=1$ for Vin1=Vin2 with gain limitation [0.25 et 4]

\section{Experimental results}

In this section we present experimental results performed with a cascaded four switch DC-DC Buck-Boost converter (FSBB) [10]. This structure allows functioning as a step down voltage or as a step up voltage. FSBB is principally characterized by a common inductance between the two stages. There are three operating modes described in [10],[11] : the buck mode when the voltage gain is less than 0.95, the boost mode when the gain is greater than 1.05 and an intermediate mode when the gain is $\pm 5 \%$ of unity. Four switches are controlled via a 30F2020 microcontroller to generate four duty cycle signals D1 for the buck, D2 for the boost and their complementary signals working at a switching frequency of $200 \mathrm{kHz}$. During intermediate operation, all switches are switched; and duty cycles are given as D1 $+\mathrm{D} 2=1$. We can already say that in this mode the losses will be greater than when operating in boost or buck because all switches are switched during the cutting. Fig. 9 show the electrical schema of the converter, designed to respond to the limit current and limit voltage of a photovoltaic panel TENESOL TE2200 240Wc with $\mathrm{V}_{\mathrm{IN}}=37 \mathrm{~V}, \mathrm{I}_{\mathrm{IN}}=8.3 \mathrm{~A}, \mathrm{~V}_{\mathrm{OUT}}=60 \mathrm{~V}$ and $\mathrm{I}_{\mathrm{OUT}}=1 \mathrm{~A}$. 


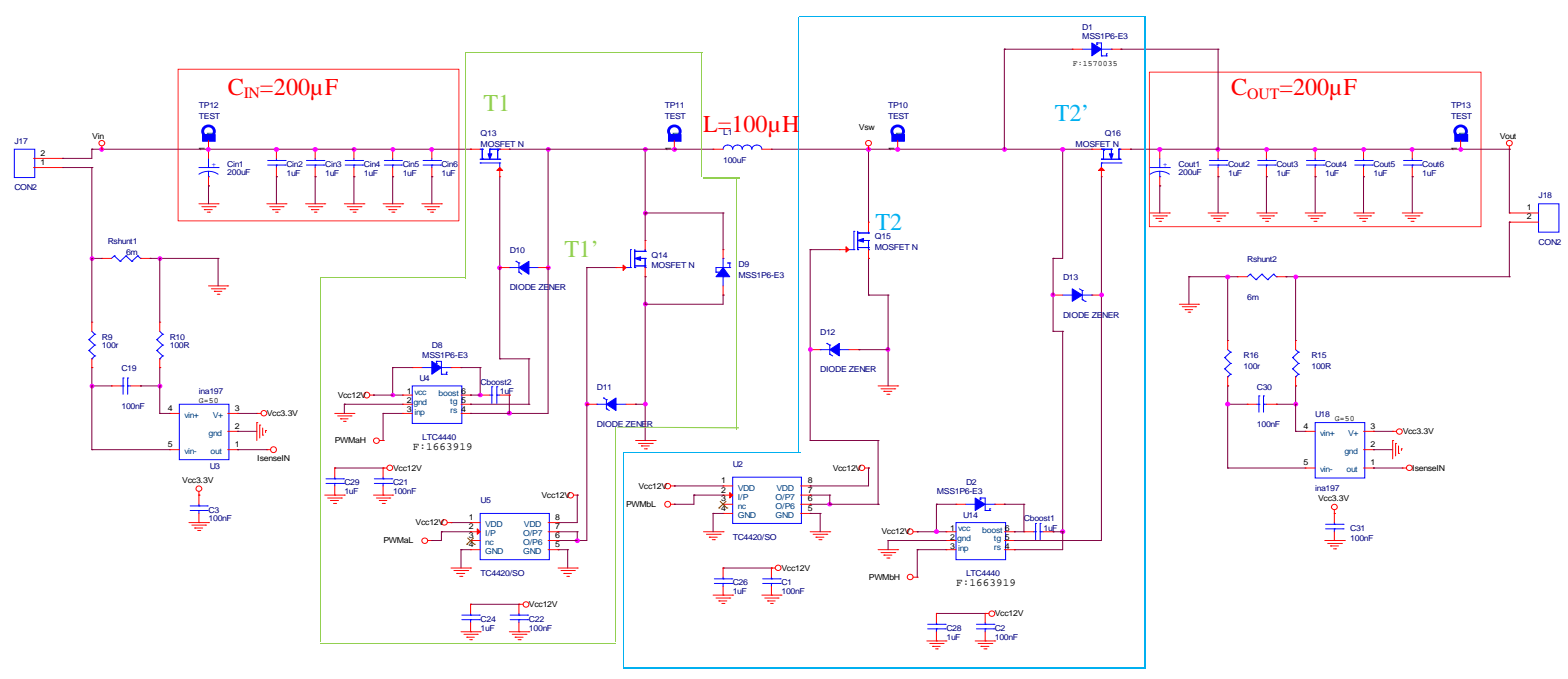

Fig. 9. Electrical schema of the Buck Boost converter

Efficiency of the DC-DC converter according to the total duty cycle define as the addition of the duty cycle D1 of the buck converter and the duty cycle D2 of the boost converter is present Fig. 10.a. We can see that the maximum efficiency is around $93 \%$ for a duty cycle around $100 \%$. Another analyze is realized in Fig. 10.b where the voltage gain is compare to the total duty cycle. Under these conditions, we can distinguish the mode buck from the mode boost when the gain is at 1 . This curve allows seeing the maximal voltage gain of 4.5 for a boost duty cycle of $85 \%$.

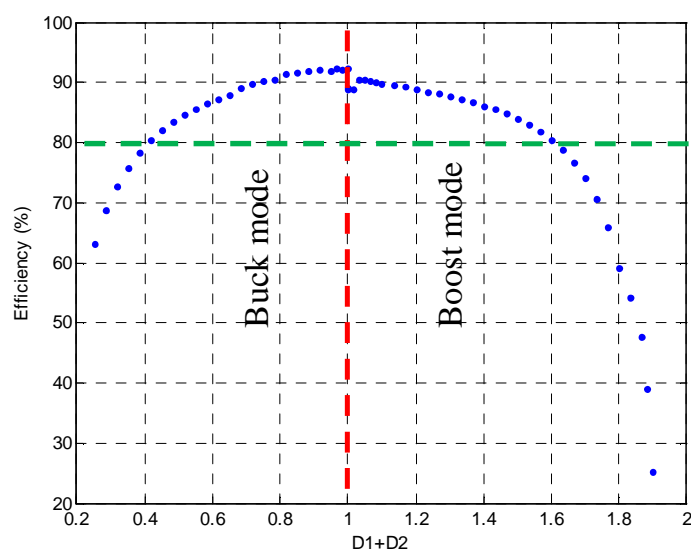

a) Efficiency Vs input current

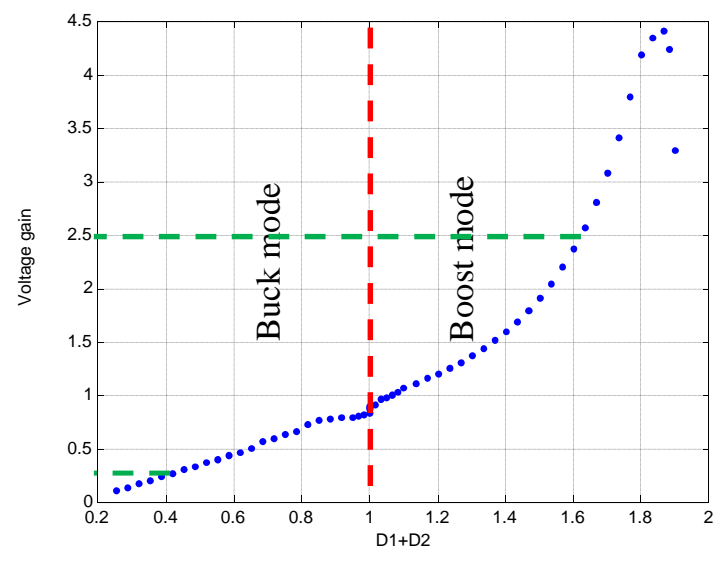

b) Voltage gain Vs duty cycle

Fig. 10. Experimental resuls of the cascaded buck boost converter (FSBB)

By analyzing the two characteristics for a minimum efficiency of $80 \%$, we can define a minimum gain of 0.25 and a maximum gain of 2.5. From these experimental results we can reproduce the 3D view presented in Fig. 11.a. Results obtained correlate the simulation, we can see the different areas of operation depending on the voltage gain, the current ratio 'B' and the ratio of voltage 'A'. Finally by adding the gain of the two conversion stages, we obtain the total gain of the structure according to the ratio of the currents. Maximum performance is obtained for currents $\mathrm{I}_{\mathrm{IN} 1} \mathrm{I}_{\mathrm{IN} 2}$ equivalent. Taking into account the performance we can see the area in which we can get the maximum production of our two modules connected to the inputs of DC-DC converters. 


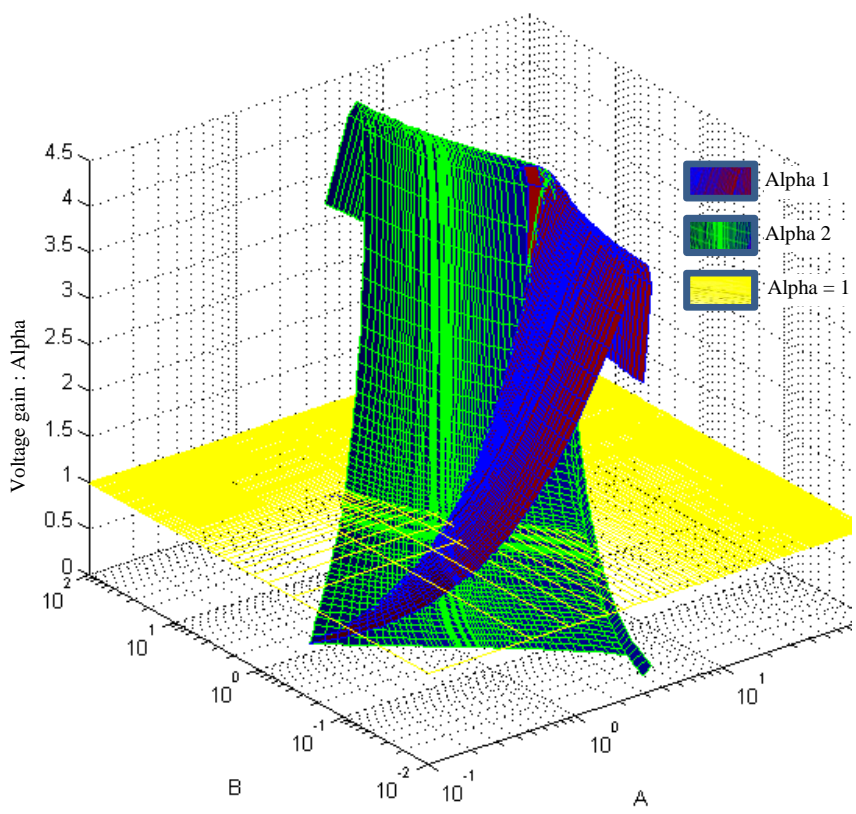

a) 3D view for two FSBB converter with the output connected in series.

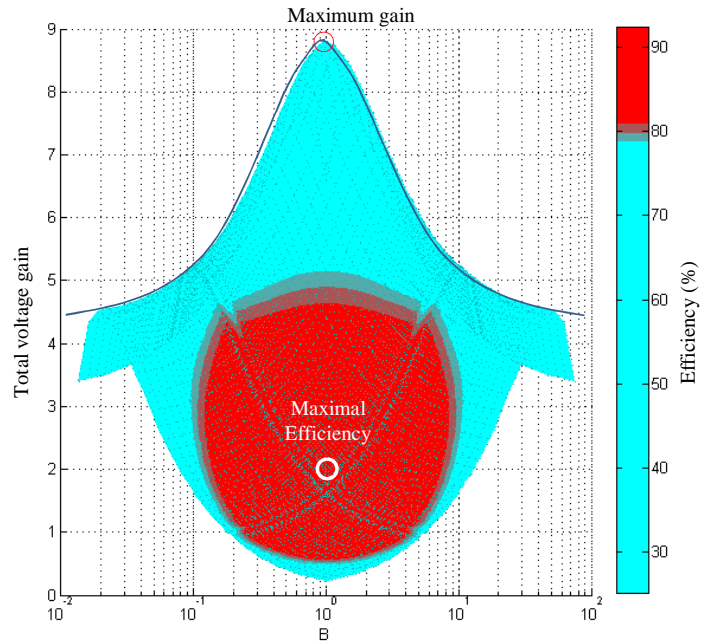

b) Total gain of the two FSBB converter vs efficiency.

Fig. 11. Conversion gain between the voltage ratio and the current ratio for Vin $1=$ Vin2.

\section{Conclusions and perspectives}

Residential facilities are the most affected by shading, especially in urban areas, which may be faced with sometimes complex phenomena shading.

These phenomena are difficult to avoid, linked to other nearby homes and urban furniture. This represents the operating conditions where the impact of shading on the energy yield is the most important. Thus, the shade worn due to chimneys, antennas, trees, clouds, or any mobile shadow moving on the modules during the day cannot be avoided. Similarly, we can add to the list of localized shadows that will be fixed in one or more cells: those primarily related soiling, bowel movements of birds, the trees, or any other deposit made by the various weather conditions. These shades will primarily generate electric producible losses generating more or less gap from its theoretical potential, but if these obstacles to sunlight persist, they can also lead to premature deterioration of the PV generator.

In this paper we make a theoretical analysis of the connection limits of two DC-DC converters which their output are connected in series. Experimental results are realized thanks a FSBB converter which allows us to define the limitation due to DC-DC converter behavior and the limitation due to the efficiency.

It can deduce for example that in the ideal case these kind of solution ensure the extraction of maximum power point of each PV modules. Therefore, in the real case, the limitation of the gain does not fully guarantee that this research is successful. Moreover the increasing of the number of stages greatly limits the allowable gap between modules. The MPPT controls operate independently and optimizing the input power of the converter, they can then stabilize at a different operating point of the PPM or even become unstable.

\section{References}

[1] PETIBON Stéphane, « Nouvelles architectures distribuées de gestion et de conversion de l'énergie pour les applications photovoltaïques », UNIVERSITÉ DE TOULOUSE, Toulouse, 2009. 
[2] R. Alonso, P. Ibaez, V. Martinez, E. Román, et A. Sanz, « An innovative perturb, observe and check algorithm for partially shaded PV systems », Power Electron. Ldots, 2009.

[3] C. A. Ramos-Paja, G. Spagnuolo, G. Petrone, M. Vitelli, et J. D. Bastidas, « A multivariable MPPT algorithm for granular control of photovoltaic systems », in 2010 IEEE International Symposium on Industrial Electronics (ISIE), 2010, p. 3433 $\square 3437$.

[4] R. Orduz, J. Solórzano, M. Á. Egido, et E. Román, «Analytical study and evaluation results of power optimizers for distributed power conditioning in photovoltaic arrays », Prog. Photovolt. Res. Appl., 2011.

[5] L. PROTIN et S. ASTIER, «Convertisseurs photovoltaïques », $\mathrm{n}^{\mathrm{o}}$ ref. article : d3360, 2013.

[6] I. Caluianu, G. Notton, I. Colda, S. Caluianu, et A. Damian, «Photovoltaic energy generation under partially shading conditions », Ldots Motion Syst. Ldots, $\mathrm{n}^{\circ}$ July, p. 1-3, 2009.

[7] C. Cabal, «Optimisation énergétique de l'étage d'adaptation électronique dédié à la conversion photovoltaïque », Université Paul Sabatier - Toulouse III, 2008.

[8] M. J.V., G. Nofuentes, J. Aguilera, M. Fuentes, et P. G. Vidal, Procedure to carry out quality checks in photovoltaic grid-connected systems: Six cases of study, ELSEVIER., vol. 88. 2011.

[9] E. S. Hasyim, S. Wenham, et M. Green, «Shadow tolerance of modules incorporating integral bypass diode solar cells », Sol. Cells, vol. 19, p. 109-122, 1986.

[10] M. Orellana, S. Petibon, B. Estibals, et C. Alonso, «Four Switch Buck-Boost Converter for Photovoltaic DCDC power applications », présenté à IECON 2010, 36th Annual Conference on IEEE Industrial Electronics Society, 2010, p. $469 \square 474$.

[11] M. Orellana, B. Estibals, A. Cid Pastor, Y. El Basri, L. Seguier, et C. Alonso, « A High Efficiency Photovoltaic Conversion Chain based on a Four-Switch Buck-Boost Converter», in International conference on renewable energies and power quality, Santiago de Compostela, Spain, 2012. 